\title{
Comment: Foreign Contracts and U.S. Copyright Termination Rights: What Law Applies?
}

\author{
Richard Arnold* and Jane C. Ginsburg**
}

\begin{abstract}
The U.S. Copyright Act gives authors the right to terminate assignments of copyrights in works other than works for hire, executed on or after January 1, 1978, after thirty-five years, and to do so notwithstanding any agreement to the contrary. Given that agreements which are subject to the laws of other countries can assign U.S. copyrights, and purport to do so in perpetuity, U.S. law's preclusion of agreements contrary to the author's right to exercise her termination right can give rise to a difficult choice of law issue. Two recent cases which came before courts in the U.S. and England respectively, Ennio Morricone Music Inc. v. Bixio Music Group Ltd. and Gloucester Place Music Ltd v. Le Bon illustrate the problem. In neither case was the choice of law question disputed by the parties, and hence neither court had occasion fully to analyze it. Nevertheless, the Court of Appeals for the Second Circuit in the Morricone case made an observation about the nature of U.S. copyright which has a potentially important bearing on the matter. In this article we consider the choice of law issue from the perspectives of U.S. law and English law.

Under either law, the key question is what law governs the permissible scope of an author's grant. Given that copyright is territorial, as a matter of principle, one would expect that law to be the lex loci protectionis, and that is essentially what both U.S. law and English law stipulate. Where the copyright is a U.S. copyright, application of the lex loci protectionis in accordance with the conceptualization suggested by Morricone, concerning the inalienable character of the right, leads to the conclusion that $\S 203$ cannot be overridden by a contract subject to a different law. We do not conclude, however, that a multinational grant will incorporate every national law limitation on the scope of the grant. Limits on the scope of the grant which are substantive, when characterized in accordance with the lex loci protectionis, must be given effect, but not limits which are evidential or procedural.

\footnotetext{
* Judge of the Court of Appeal of England and Wales.

** Morton L. Janklow Professor of Literary and Artistic Property Law, Columbia University School of Law.

(C) 2020 Richard Arnold \& Jane C. Ginsburg. This is an open access article distributed under the terms of the Creative Commons Attribution-NonCommercial-NoDerivatives License, which permits noncommercial use, distribution, and reproduction, provided the original authors and source are credited, and the article is not changed.
} 
TABLE OF CONTENTS

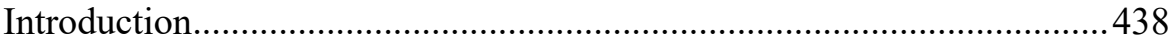

I. The Termination Right and Recent Cases .........................................439

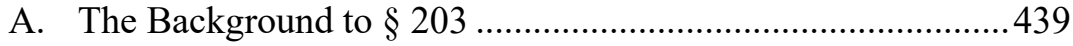

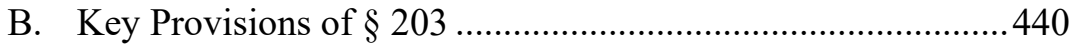

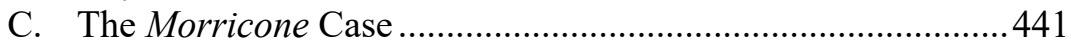

D. The Gloucester Place Case .......................................................443

II. Choice of Law from the Perspective of U.S. Law ..................................444

III. Choice of Law from the Perspective of English Law .........................446

A. English Common Law ...................................................... 446

B. The Rome Convention................................................................446

C. The Rome I Regulation ...........................................................44

D. Application of the Law to Assignments of Copyright..............448

E. Termination Under $\S 203$ and English Law Contracts .............449

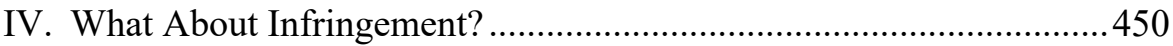

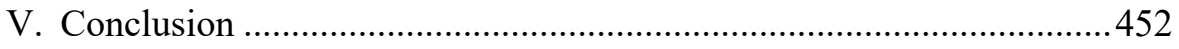

\section{INTRODUCTION}

The U.S. Copyright Act, specifically 17 U.S.C. § 203, gives authors the right to terminate assignments of copyrights in works other than works for hire, executed on or after January 1, 1978, after thirty-five years, and to do so notwithstanding any agreement to the contrary. Given that assignments of U.S. copyrights may be effected by agreements which are subject to the laws of other countries, this can give rise to a difficult choice of law issue. This is illustrated by two recent cases which came before courts in the U.S. and England respectively, Ennio Morricone Music Inc. v. Bixio Music Group Ltd. ${ }^{1}$ and Gloucester Place Music Ltd v. Le Bon, ${ }^{2}$ in which the authors were involved respectively as advocate and judge. In neither case was the choice of law question disputed by the parties, and hence neither court had occasion fully to analyze it. Nevertheless, the Court of Appeals for the Second Circuit in the Morricone case made an observation about the nature of U.S. copyright which has a potentially important bearing on the matter. In this Comment we will consider the choice of law issue from the perspectives of U.S. law and English law.

1. 936 F.3d 69 (2d Cir. 2019).

2. [2016] EWHC 3091 (Ch), [2017] FSR 27 (Eng.). 


\section{THE TERMINATION RIGHT AND RECENT CASES}

\section{A. The BACKground To $§ 203$}

From the outset, every U.S. copyright law has included authors' reversion rights. ${ }^{3}$ The first Copyright Act, from 1790, borrowed from section 11 of the 1710 Statute of Anne in establishing an initial fourteen-year term of copyright, and providing that "if, at the expiration of the said term, the author or authors, or any of them, be living, and a citizen or citizens of these United States, or resident therein, the same exclusive right shall be continued to him or them, his or their executors, administrators or assigns, for the further term of fourteen years ...." Early U.S. case law on reversion rights recognized the second term of copyright as a "new interest" that was "made to benefit authors." 5 Because the renewal term was considered a "new estate," all rights returned to the author, thus superseding prior contracts. ${ }^{6}$ Every copyright revision prior to the present 1976 Copyright Act maintained the two-term duration (albeit doubling the length of the initial and renewal terms), with authors' reversion contingent on renewing the registration of copyright in order to obtain the second term. ${ }^{7}$ The Supreme Court, however, significantly undermined the ability of the reversion right to "benefit authors" when it ruled that the author's first-term assignment of the second term bound him to convey the renewal term to the original publisher. ${ }^{8}$ Because most book and music publishing contracts routinely - since at least the 1870s - systematically and explicitly conveyed both the first and the renewal terms, ${ }^{9}$ generally with no separate consideration for the latter, the Court's ruling validated industry practice, but arguably at the cost of the raison d'etre of the reversion right. By contrast, if the contract of transfer did not explicitly cover the renewal term, many courts declined to deem it included within the scope of the grant. As the Second Circuit noted, in a case involving a grant of "full ownership ... in all countries of the world" of the copyright in a musical composition, "[t]he presumption against conveyance of renewal rights serves the congressional purpose of protecting authors' entitlement to receive new rights in the 28th year of the original term." 10 Thus, an assignment of rights in "the copyright term" would not suffice to convey

3. For detailed analysis of legislation and caselaw regarding U.S. reversion rights, see Lionel Bently \& Jane C. Ginsburg, "The Sole Right . . Shall Return To the Authors": Anglo-American Authors' Reversion Rights from the Statute of Anne To Contemporary U.S. Copyright, 25 BERKELEY TECH. L.J. 1475 (2010).

4. An Act for the Encouragement of Learning, by Securing the Copies of Maps, Charts, and Books, To the Authors and Proprietors of Such Copies, During the Times Therein Mentioned, ch. XV, $\S 1,1$ Stat. 124 (May 31, 1790).

5. Pierpont v. Fowle, 19 F. Cas. 652, 659-60 (C.C.D. Mass. 1846) (No. 11,152).

6. See, e.g., Stewart v. Abend, 495 U.S. 207, 226, 230 (1990).

7. An Act To Amend the Several Acts Respecting Copy Rights, ch. XVI, § 2, 4 Stat. 436 (Feb. 3 , 1831); An Act To Amend and Consolidate the Acts Respecting Copyright, ch. CCCXX, § 24, 35 Stat. 1075 (Mar. 4, 1909).

8. Fred Fisher Music Co. v. M. Witmark \& Sons, 318 U.S. 643 (1943).

9. See Bently \& Ginsburg, supra note 3, at 1563.

10. Corcovado Music Corp. v. Hollis Music, Inc., 981 F.2d 679, 684 (2d Cir. 1993). 
the renewal term rights. ${ }^{11}$ Similarly, because the renewal term was considered a "separate interest," courts protective of authors' reversion rights might interpret a grant of "all right, title and interest in and to the copyright" to apply only to the first term. ${ }^{12}$ On the other hand, contract language - even if lacking the specification "all renewals and extensions thereof," which denoted intent to transfer the renewal term — such as "exclusive right to ... use . . f forever," could rebut the presumption. ${ }^{13}$

Alienability of the reversion right proved one of the signal concerns of the twentyyear revision process that produced the 1976 Copyright Act. Congress abandoned the two-term structure of duration in order to adopt the international standard of fifty years post mortem auctoris. In the absence of a renewal term, Congress recognized the need for "a provision safeguarding authors against unremunerative transfers. A provision of this sort is needed because of the unequal bargaining position of authors, resulting in part from the impossibility of determining a work's value until it has been exploited." 14 Congress therefore provided for authors' right to terminate grants within a period of years subsequent to the conclusion of the contract. Unlike the "new estate" of the renewal term, rights did not revert automatically: Congress made termination contingent on the author's timely service of notice on the grantee and filing with the Copyright Office. If the author failed to effect termination (or to do so correctly), no rights reverted. On the other hand, "although affirmative action is needed to effect a termination, the right to take this action cannot be waived in advance or contracted away." 15 Notwithstanding publishers' objections that "[t]here is no adequate reason why the well-entrenched doctrine of non-governmental interference with freedom of contract should not be applied to this situation," 16 every draft of the bill from 1964 onward nullified any contractual provision contrary to the author's right to terminate.

\section{B. Key Provisions of $§ 203$}

The 1976 Act allows the author or her heirs to terminate grants of exclusive or nonexclusive rights made by the author after 1977 (regardless of the work's date of publication). But not all creators are "authors" under the 1976 Copyright Act. "In the case of a work made for hire, the employer or other person for whom the work was prepared is considered the author for purposes of this title, and, unless the parties have expressly agreed otherwise in a written instrument signed by them, owns all of

11. See, e.g., Edward B. Marks Music Corp. v. Charles K. Harris Music Publ'g Co., 255 F.2d 518, 521 (2d Cir. 1958) ("The cases are clear that a copyright renewal creates a separate interest distinct from the original copyright and that a general transfer by an author of the original copyright without mention of renewal rights conveys no interest in the renewal rights without proof of a contrary intention.").

12. See, e.g., Rossiter v. Vogel, 134 F.2d 908, 911 (2d Cir. 1943) (holding "all rights, title and interest" transfer at outset of first copyright term insufficient to convey renewal term: "the circumstances justifying the transfer of the right of renewal must be stronger than those justifying the transfer of the copyright, since the right of renewal is separate from the original copyright").

13. Siegel v. Nat'l Periodical Publ'ns, Inc., 508 F.2d 909, 913-14 (2d Cir. 1974).

14. H.R. REP. NO. 94-1476, at 124 (1976).

15. Id. at 125 .

16. StafF OF H. COMM. ON THE Judiciary, 89Th CONG., COPYRight LAW Revision PT. 5, 1964 REVISION BILl WITH Discussions AND COMMENTS 225 (Comm. Print 1965). 
the rights comprised in the copyright." 17 There is no termination of a grant in a work made for hire. ${ }^{18}$ The statute defines a "work made for hire" as either one created by an employee in the course of employment, or a specially ordered or commissioned work coming within one of nine limitedly enumerated categories, provided the creator and the commissioning party sign an agreement stating that the work will be for hire. ${ }^{19}$

The author must effect termination within a five-year period beginning thirty-five years from execution of the grant (or, if the grant transferred publication rights, thirty-five years from publication or forty years from execution, whichever is earlier), with a minimum of two years', and a maximum of ten years', advance notice. ${ }^{20}$ After termination, most rights revert to the author, but there is an important exception for already-created derivative works: The transferee may continue to exploit them under the terms of the terminated agreement. ${ }^{21}$ The transferee may not, however, prepare new derivative works once the author terminates. The parties may not derogate from the reversion right: The statute states that authors enjoy the right "notwithstanding any agreement to the contrary.",2

\section{The Morricone CASE}

Ennio Morricone is an Italian composer well-known for his film scores. In the late 1970s and early 1980s Edizioni Musicali Bixio, an Italian music publisher, commissioned Morricone to compose the scores for six Italian films. The parties entered into six agreements which were identical in all material respects. Each agreement required Morricone to compose and arrange the musical score for the film in question (and to conduct the orchestra when the score was recorded). In exchange for an upfront payment and ongoing royalties, Morricone transferred his worldwide rights in the score to Bixio. The wording of the assignment was (in English translation) as follows:

"You do hereby grant and transfer to us, exclusively, for the maximum total duration permitted by the laws in force in each country in the world, and at the conditions

\footnotetext{
17. 17 U.S.C. $\S 201$ (b) (2016).

18. Id. § 203(a).

19. Id. $\S 101$.

20. Id. §203(a)(3).

21. Id. §203(b)(1). The derivative works and works for hire exceptions were almost certainly necessary to obtain the agreement of the motion picture industry to any kind of termination right. See Copyright Law Revision: Hearings Before Subcomm. No. 3 of the H. Comm. on the Judiciary, 89th Cong. 998 (1965) (memorandum statement by the Copyright Comm. of the Motion Picture Association of America, Inc. on H.R. 4347) ("Although we are still strongly opposed in principle to the very concept of statutory recapture in any form, the compromise worked out, after much travail, in H.R. 4347, is a minimal basis on which we can learn to live with such a provision, and accept the same in the interests of furthering an adequate revision statute.").

22. 17 U.S.C. § 203(a)(5) (2016) ("Termination of the grant may be effected notwithstanding any agreement to the contrary, including an agreement to make a will or to make any future grant.").
} 
established here below, all the rights of economic use, in any country in the world, with regard to the works ....",23

In 2012, Morricone's assignee served Bixio (or, more precisely, the administrator of its U.S. copyrights) with a notice terminating the assignments under $\S 203$. Bixio contested the validity of the terminations on the ground that the scores were works made for hire, and therefore excluded from the right of termination. It was common ground between the parties that the agreements were governed by Italian law, and that Italian law was the law applicable to this issue. ${ }^{24}$

The Second Circuit held that the scores were not works made for hire. It reasoned that Italian law allocated authorship status differently from U.S. law. Under $\S 201$ (b), in the case of a work made for hire, the commissioner of the work was deemed to be its author (if all statutory prerequisites were met), and owned all the rights in it, $a b$ initio. That was why works made for hire were excepted from the right of termination under $\S 203$. By contrast, under Italian law, there was no doctrine of works for hire which resulted in the commissioner being deemed the author of a work, and first owner of copyright in it. Rather, the author was the first owner of copyright. $^{25}$ Italian law permitted the author to assign all his rights to the commissioner, and in the present case Morricone had done so. The form of the assignment, however, presupposed that Morricone was the first owner of the rights. ${ }^{26}$

Bixio did not argue that the wording of the assignments precluded Morricone from exercising his rights of termination, and therefore the court did not have to consider the applicability of $\S 203(\mathrm{a})(5)$ in circumstances where the agreements were governed by Italian law. Nevertheless, Circuit Judge Dennis Jacobs observed:

"As an initial matter, the transfer of 'all the rights of economic use' was for the 'the maximum total duration permitted by the laws in force in each country in the world.' ... The maximum total duration permitted by the laws of the United States is thirty-five years plus such additional period as the assignor allows until the exercise of the option to terminate. The contract wording therefore does not foreclose termination under $\S 203 ., 27$

23. Ennio Morricone Music Inc. v. Bixio Music Grp. Ltd., 936 F.3d 69, 70 (2d Cir. 2019).

24. The Court referred in a footnote to Itar-Tass Russian News Agency v. Russian Kurier, Inc., 153 F.3d 82 (2d Cir. 1998). As discussed below, this holds that the law of the source country governs the initial ownership of copyrights.

25. More precisely, Italian copyright law transfers the rights of cinematographic exploitation of commissioned musical scores to the film producer by operation of law. The composer remains the first owner of the copyright in the score apart from its cinematographic exploitation. See Legge 22 aprile 1941, n. 633 , in G.U. July 16, 1941, n. 166, arts. 44-50, as amended, https://perma.cc/AM4K-3RN4 (English translation).

26. Even if it were to be held, contrary to Itar-Tass v. Russian Kurier, that the law applicable to the initial ownership of a U.S. copyright was U.S. law, rather than the law of the source country, that would not necessarily undermine the Court's conclusion. On that hypothesis, the question would remain whether the effect of the Italian law contracts was that the scores were works made for hire for the purposes of U.S. copyright law. Although the works made for hire doctrine is expansive, it is not unlimited. It would still have been open to the Court to conclude that the contracts were inconsistent with the scores being works made for hire.

27. Morricone, 936 F.3d at 73 (emphasis added). 
This remark is important, because it suggests that a U.S. copyright should be conceptualized as being inherently contingent upon the author's exercise (or not) of her right of termination. The relevance of this will become clear below.

\section{The Gloucester Place Case}

On July 28, 1980, each of the members of Duran Duran, an English pop group which was very successful in the 1980s, entered into music publishing agreements by which the members of the group assigned their rights in future musical compositions and lyrics to Gloucester Place. On June 1, 1983, each of the members' service companies entered into similar agreements. The key provision was clause 3(a) of the 1980 agreements, which provided:

"The Writer . . . hereby assigns to the Publishers all the copyrights and all other rights whatsoever . . . in all musical compositions and/or lyrics . . . which may during the term hereof be written composed or created in whole or in part by the Writer . . . throughout the world and the right to renew and extend such copyrights and other rights and the ownership of such renewed and extended copyrights and other rights as may now or hereafter be conferred by the laws of any territory so that the entire copyrights and all other rights in the said works shall be vested in the Publishers absolutely . . .."28

The agreements provided that they were governed by English law.

The members of the group and their service companies served notices of termination under $\S 203$ with respect to thirty-seven songs. Gloucester Place claimed that they had thereby acted in breach of the agreements. It was common ground between the parties that the applicable law was English law, and no evidence as to U.S. law was adduced. Furthermore, it was common ground that: (1) U.S. copyrights of the kind at issue were assignable for their full term; (2) an assignment of U.S. copyright for the full term of copyright was effective throughout that term unless and until the author served notice of termination under $\S 203$; (3) the effect of clause 3(a) of the agreements was to transfer the U.S. copyrights in the songs to Gloucester Place; and (4) the notices of termination were valid and effective as a matter of U.S. law.

The dispute between the parties was as to the correct interpretation of the agreements applying English law. Gloucester Place contended that the members assigned their U.S. copyrights to Gloucester Place for the full term of those copyrights and that, in the absence of any express contractual reservation by the members of the right of termination under $\S 203$, the exercise of that right was precluded. The members of Duran Duran contended that the U.S. copyrights which they assigned were inherently subject to the right of termination and that, in the absence of any express contractual prohibition upon the exercise of that right, the members were free to do so. Arnold J considered that these arguments were finely balanced, but concluded that Gloucester Place's interpretation was the correct one. He gave the members of the group permission to appeal to the Court of Appeal, and subsequently, the members' appeal was settled out of court on undisclosed terms.

28. Gloucester Place Music Ltd v. Le Bon [2016] EWHC 3091 (Ch) [6], [2017] FSR 27 (Eng.). 


\section{CHOICE OF LAW FROM THE PERSPECTIVE OF U.S. LAW}

In Itar-Tass v. Russian Kurier, the Second Circuit announced choice of law rules for cases involving foreign copyright works:

Conflicts rule for issues of [initial] ownership. Copyright is a form of property, and the usual rule is that the interests of the parties in property are determined by the law of the state with "the most significant relationship" to the property and the parties. ... Since the works at issue were created by Russian nationals and first published in Russia, Russian law is the appropriate source of law to determine issues of ownership of rights. ... In terms of the United States Copyrights Act and its reference to the Berne Convention, Russia is the "country of origin" of these works . ...

To whatever extent we look to the Berne Convention itself as guidance in the development of federal common law on the conflicts issue, we find nothing to alter our conclusion. The Convention does not purport to settle issues of ownership ....

Conflicts rule for infringement issues. On infringement issues, the governing conflicts principle is usually lex loci delicti, the doctrine generally applicable to torts. We have implicitly adopted that approach to infringement claims, applying United States copyright law to a work that was unprotected in its country of origin. In the pending case, the place of the tort is plainly the United States. To whatever extent lex loci delicti is to be considered only one part of a broader "interest" approach, United States law would still apply to infringement issues, since not only is this country the place of the tort, but also the defendant is a United States corporation.

... [I]n some cases, including the pending one, the issue is not simply who owns the copyright but also what is the nature of the ownership interest [i.e. what is the scope of the rights the plaintiff allegedly owns].... Whether a copy infringes depends in part on the scope of the interest of the copyright owner. Nevertheless, though the issues are related, the nature of a copyright interest is an issue distinct from the issue of whether the copyright has been infringed. ${ }^{29}$

While U.S. courts (or at least the Second Circuit) look to the country of origin to determine initial copyright ownership, and to the law of the country where the wrongful act allegedly occurred to adjudicate claims of infringement, Itar-Tass leaves out an additional choice of law category: the law applicable to determine the scope of a grant. In other words, what law governs the determination of which rights the author assigned when her contract granted rights for multiple territories? Suppose the law chosen by the parties to govern the contract permits unrestricted assignments of copyright, covering all rights for the full period of copyright. Suppose also, however, that the laws of the countries for which the contract granted rights impose restrictions respecting the nature of the rights which may be granted (for example, designating moral rights as inalienable ${ }^{30}$ ), or the duration of the grant (for example, limiting the grant to a term of years), or concerning the specificity of

29. Itar-Tass, 153 F.3d at 90-91 (citations omitted).

30. As in, for example, French copyright law. See CODE DE LA PROPRIETE inTELleCtuelle [C.P.I.] art. L. 121-1. 
the grant (for example, permitting the transfer of future technology rights, but only if the contract says so explicitly, and provides for additional remuneration ${ }^{31}$ ). If the law of the contract governs the scope of the grant, then the contract effectively makes it possible to transfer rights for territories whose domestic laws prohibit or limit such grants. Consider a variation on Gloucester Place: In 1975, in a contract governed by a national law that permits unrestricted assignments, Author grants Publisher 1 all rights for all territories for a lump sum; at the time, e-books were unknown. In 2000, Author grants e-book rights to local publishers in countries whose laws reserve new technology rights to authors unless the contract states explicitly that new technology rights are included and are separately remunerated. Publisher 1 sues Author for breach of contract for granting e-book rights for exploitation in territories whose laws had reserved those rights to the Author (or sues Publishers 2 and 3 for copyright infringement in those countries). Which law applies?

Other Second Circuit authority provides at least a partial answer. The case, moreover, concerned the author's reversion right under the 1909 Act. In Corcovado Music Corp. v. Hollis Music, Inc., the Second Circuit held that the Brazilian composer Antonio Carlos Jobim retained the U.S. renewal right, despite a Brazilian law contract purporting to grant "full ownership ... in all countries of the world" of the copyright in a musical composition (the Second Circuit also declined to defer to the contract's forum selection clause designating Brazil). ${ }^{32}$ Under U.S. law, Jobim was entitled to reassign the reverted U.S. rights to a U.S. publisher, notwithstanding his previous assignment of worldwide rights to the Brazilian publisher:

Factors arguing for the application of United States law include the following: United States renewal copyrights reflect a vital policy of United States copyright law; the forum in which the [composer's] contracts [with the Brazilian publisher] are to be construed is in the United States ... ; and the place of performance of the contracts is also the United States. Under these circumstances, we believe that United States law is applicable. $^{33}$

In emphasizing the "place of performance," the Court recognized that copyright is territorial, and national law defines the scope and manner of what can be granted for that territory, particularly when "vital polic[ies]" underlie restrictions on the scope of what may be granted. ${ }^{34}$ The Court acknowledged that renewal term rights could be granted, but "there is a strong presumption against the conveyance of renewal rights .... The presumption against conveyance of renewal rights serves the congressional purpose of protecting authors' entitlement to receive new rights ...."35 As a result, at least with respect to authors' reversion rights (and perhaps with respect to contractual grants generally), U.S. substantive copyright law prevails

31. As in, for example, French copyright law, id. art. L. 131-6, and German copyright law, Urheberrechtsgesetz [UrhG][Copyright Act], Sept. 9, 1965, BGBL I at 1273, last amended by Gesetz [G], Nov. 28, 2018, BGBL I at 2014, § 31a, https://perma.cc/UE8N-V859 (English translation).

32. Corcovado Music Corp. v. Hollis Music, Inc., 981 F.2d 679 (2d Cir. 1993).

33. Id. at 685 .

34. Id.

35. Id. at 684 . 
over the national law the parties chose (or the stronger party imposed on the author) to govern contractual disputes.

\section{CHOICE OF LAW FROM THE PERSPECTIVE OF ENGLISH LAW}

In order to address the choice of law issue from the perspective of English law, it is first necessary to explain the relevant European and English legal framework. It should be noted at the outset that the relevant aspects of European Union ("EU") law will continue to form part of U.K. law following the United Kingdom's departure from the EU unless and until Parliament legislates to the contrary (which is unlikely to happen for some time). ${ }^{36}$

\section{A. English Common LaW}

Contracts which were entered into prior to April 1, 1991, are subject to English common law principles of private international law. ${ }^{37}$ The basic principle is that contracts are governed by their "proper law." Where the parties have chosen a law to govern their contract, that choice will generally be respected. Where the parties have not expressly chosen a law, the court will consider whether a choice of law can be inferred from the terms and nature of the contract and the other circumstances of the case. Where the intention of the parties is not expressed and cannot be inferred, the proper law is the law of the country with which the contract has the "closest and most real connection." The proper law of the contract governs its material validity, interpretation and effect, and discharge. ${ }^{38}$ As was noted in the Gloucester Place case ${ }^{39}$ the general rule is that English courts will enforce a contract which is valid and enforceable under English law even if the contract would be unenforceable as contrary to public policy in another country with which the contract has a connection. ${ }^{40}$ English courts will not, however, enforce a contract the performance of which would be unlawful in its place of performance. ${ }^{41}$

\section{B. The Rome Convention}

Contracts which were entered into between April 1, 1991, and December 17, 2009, are subject to the EEC Convention on the Law Applicable to Contractual

36. This is because the relevant Regulations and Directives constitute "retained EU law" under the European Union Withdrawal Act 2018, which means that they are incorporated into domestic law.

37. Note that this point was overlooked in the Gloucester Place case, where it was wrongly assumed that the Rome Convention applied.

38. See Dicey, MORRIS \& COLLINS ON THE CONFLICT OF LAWS 32-004-32-008 (Lawrence Collins \& Jonathan Harris, eds.,15th ed. 2012).

39. Gloucester Place Music Ltd. v. Le Bon [2016] EWHC 3091 (Ch), [2017] FSR 27 [25] (Eng.).

40. See In re Mo. Steamship Co. [1889] 42 Ch D 321 at 335-37 (Lord Halsbury LC) (Eng.); Vita Foods Products, Inc. v. Unus Shipping Co., Ltd. [1939] AC 277 at 296-98 (Lord Wright) (Eng.).

41. See, e.g., Ispahani v. Bank Melli Iran [1998] Lloyd's Rep. Bank 133 at 136-37 (Robert Walker LJ) (Eng). 
Obligations (the "Rome Convention") ${ }^{42}$ to the extent that it is given the force of law in the United Kingdom by section 2 of the Contracts (Applicable Law) Act 1990.43 Article 3 of the Rome Convention generally requires the court to give effect to the parties' choice of law, subject to the provisions of Articles 5 and 6 concerning consumer contracts and employment contracts. Article 4 of the Convention contains rules for determining the applicable law where the parties have not chosen it. The applicable law determines the parties' contractual obligations, including questions of material validity (Article 8(1)), interpretation (Article 10(1)(a)), and performance (Article 10(1)(b)).

It is important to note that, under section 2(2) of the Contracts (Applicable Law) Act, Article 7(1) of the Rome Convention (which provides that "effect may be given to the mandatory rules of the law of another country with which the situation has a close connection" ${ }^{\prime 4}$ ) does not have the force of law in the United Kingdom. ${ }^{45}$ On the other hand, Article 3(3) does have the force of law. This Article provides:

The fact that the parties have chosen a foreign law ... shall not, where all the other elements relevant to the situation at the time of the choice are connected with one country only, prejudice the application of rules of the law of that country which cannot be derogated from by contract. ${ }^{46}$

\section{THE ROME I REgUlation}

Contracts which were entered into after December 17, 2009, are subject to EC Regulation 593/2008 (the "Rome I Regulation"). ${ }^{47}$ Unlike the Rome Convention, which as an international convention required domestic legislation for it to have effect in English law, the Rome I Regulation has direct effect. Article 3 of the Rome I Regulation generally requires the court to give effect to the parties' choice of law subject to the provisions of Articles 6, 7, and 8 concerning consumer contracts, insurance contracts, and employment contracts. Article 4 of the Regulation contains rules for determining the applicable law where the parties have not chosen it. The applicable law determines the parties' contractual obligations, including questions of material validity (Article 10(1)), interpretation (Article 12(1)(a)), and performance (Article 12(1)(b)).

Like the Rome Convention, the Rome I Regulation has two mandatory rules which are potentially relevant. Article 3(3) provides:

Where all other elements relevant to the situation at the time of the choice are located in a country other than the country whose law has been chosen, the choice of the parties

42. Convention on the Law Applicable to Contractual Obligations 80/934/EEC, opened for signature June 19, 1980, 1980 O.J. (L 266) [hereinafter Rome Convention].

43. Contracts (Applicable Law) Act 1990, c. 36, § 2 (UK).

44. Rome Convention, supra note 42, art. 7(1).

45. Contracts (Applicable Law) Act 1990, c. 36, § 2(2) (UK).

46. Rome Convention, supra note 42, art. 3(3).

47. Regulation 593/2008/EC of the European Parliament and of the Council of 17 June 2008 on the Law Applicable to Contractual Obligations, 2008 O.J. (L 177). 
shall not prejudice the application of provisions of the law of the other country which cannot be derogated from by agreement. ${ }^{48}$

Article 9(3) provides:

Effect may be given to the overriding mandatory provisions of the law of the country where the obligations arising out of the contract have to be or have been performed, in so far as those overriding mandatory provisions render the performance of the contract unlawful. ${ }^{49}$

"Overriding mandatory provisions" are defined in Article 9(1) as "provisions the respect for which is regarded as crucial by a country for safeguarding its public interests, such as its political, social or economic organization, to such an extent that they are applicable to any situation falling within their scope, irrespective of the law otherwise applicable to the contract." 50 The Court of Justice of the European Union has held that, in order to give full effect to the principle of freedom of contract, which is the cornerstone of both the Rome Convention and the Rome I Regulation, these provisions must be interpreted strictly. In considering whether the national law which the national court proposes to substitute for that chosen by the parties to the contract is a mandatory rule, the court must take account not only of the exact terms of the law, but also of its general structure and of the circumstances in which it was adopted in order to determine whether the legislature adopted it in order to protect an interest judged essential by the state in question. ${ }^{51}$

\section{Application OF The LAW TO ASSignMENTS OF COPYRIGHT}

The rule at common law is that the question whether, and to what extent, title to copyright is assignable depends on the law under which the relevant copyright was created $^{52}$ (the lex loci protectionis, that is to say, the law of the country "where protection is claimed" in the words of Article 5(2) of the Berne Convention, ${ }^{53}$ which is properly interpreted as being the law, or laws, of the country, or countries, with respect to which protection is claimed). There is no reason to think that the position is any different under either the Rome Convention or the Rome I Regulation. ${ }^{54}$

If and to the extent that title is assignable under the lex loci protectionis, the question whether, and to what extent, title has in fact been assigned by an agreement

48. Id. art. 3(3).

49. Id. art. $9(3)$.

50. Id. art. 9(1).

51. See Case C-184/12, United Antwerp Mar. Agencies (Unamar) NV v. Navigation Mar. Bulgare, EU:C:2013:663 99 48-50 (May 15, 2013) (concerning Article 7(2) of the Rome Convention).

52. See Campbell Connelly \& Co. Ltd. v. Noble [1963] 1 WLR 252 at 255 (Wilberforce J) (Eng).

53. Berne Convention for the Protection of Literary and Artistic Works art. 5(2), Sept. 9, 1886, as revised July 24, 1971, and as amended Sept. 28, 1979, S. Treaty Doc. No. 99-27 (1986). Note, however, that Article 5(2) does not concern ownership of copyright, but rather its existence and enforcement.

54. See DiceY, Morris \& COLLINS ON THE CONFLICT OF LAWS, supra note 38, at 24-069. 
governed by English law depends on the effect of the agreement applying English law, and in particular English principles of contractual interpretation. ${ }^{55}$

The effect of these principles is illustrated by Campbell Connelly v. Noble. ${ }^{56}$ U.S. copyright law in 1934 provided that the initial term of copyright was twenty-eight years. As discussed above, at the expiration of that period, the author or the author's heirs could obtain a renewal of the copyright for a further term of twenty-eight years. The renewal copyright was separate and distinct from the original copyright, and had to be separately assigned, but it could be assigned prior to the expiration of the original copyright. ${ }^{57}$ Wilberforce $\mathrm{J}$ held that an English law contract executed in 1934 which assigned "THE FULL COPYRIGHT FOR ALL COUNTRIES in the musical composition ... in all countries for the period of copyright as far as it is assignable by law, together with all rights therein which he now has or may hereafter become entitled to whether now or hereafter known" was effective to assign the renewal copyright as well as the original copyright. ${ }^{58}$

\section{E. Termination Under § 203 And English LaW Contracts}

It will be appreciated from the discussion above that it was common ground between the parties in the Gloucester Place case that the U.S. copyrights in issue were assignable for their full term and had been transferred to the claimant. The dispute presented to the court for decision was purely as to the interpretation of the contracts applying English principles of contractual interpretation. With the benefit of the subsequent decision of the Second Circuit in the Morricone case, it can now be seen that a different approach to the case on the part of the defendants might have led to a different outcome. If a U.S. copyright is conceptualized as having a maximum total duration of thirty-five years "plus such additional period as the assignor allows until the exercise of the option to terminate," 59 then one may conclude that, as a matter of U.S. law, the copyright cannot be assigned outright for the full term of copyright. In other words, an assignment of U.S. copyright would inherently be subject to the assignor's right of termination under $\S 203$ notwithstanding an agreement to the contrary. On this view of the matter, the effect of the contract of assignment under English law could not override that limitation on the assignability of U.S. copyright. ${ }^{60}$ (In any event, contracts such as those in the

55. See Peer Int'l Corp. v. Termidor Music Pubs. Ltd [2002] EWHC 2675 (Ch) [24] (Neuberger J) (Eng.), aff'd [2003] EWCA (Civ) 1156, [2004] 2 WLR 849 (Eng.). Note that there is no problem as to the justiciability of such a dispute. See Crosstown Music Co. 1, LLC v. Rive Droite Music Ltd. [2010] EWCA (Civ) 1222, [2011] FSR 5 (Eng.).

56. See Campbell Connelly [1963] 1 WLR 252 (Eng.).

57. See Fred Fisher Music Co. v. M. Witmark \& Sons, 318 U.S. 643 (1943).

58. Note that the decision was not followed in Corcovado v. Hollis, 981 F.2d 679, 685 (2d Cir. 1993) ("We believe that Campbell Connelly is distinguishable on the facts and, in any event, conclude that its reasoning could not be applied here to preclude the use of United States law.").

59. Ennio Morricone Music Inc. v. Bixio Music Grp. Ltd., 936 F.3d 69, 73 (2d Cir. 2019).

60. It was widely reported in 2017 that Paul McCartney had brought an action against Sony/ATV in the Southern District of New York for a declaratory judgment that notices of termination he had served in respect of assignments of copyright in songs he had co-authored with John Lennon were valid. See, e.g., Eriq Gardner, Paul McCartney Sues Sony to Regain Rights to Beatles Songs, Hollywood 
Morricone case, which assign rights "for the maximum total duration permitted by the laws in force in each country" necessarily incorporate the limitations in each lex loci protectionis and therefore do not purport to override them.)

In the case of contracts entered into since December 17, 2009, an alternative, but probably more difficult, route to the same result would be to argue that $\S 203$ is an "overriding mandatory provision" of U.S. law within Article 9(1) of the Rome I Regulation and that the court should exercise its discretion to give effect to it under Article 9(3). ${ }^{61}$ The first question would be whether $\S 203$ is regarded by the United States as crucial for safeguarding its public interests. Clearly, Congress enacted the termination right in order to safeguard the author's economic interests, but it may be debated whether this means that $\S 203$ is crucial for safeguarding the United States's interests. ${ }^{62}$ If it is, then the court is directed by Article 9(3) to have regard to the nature and purpose of $\S 203$ and to the consequences of its application or nonapplication when exercising its discretion. Given that $\S 203$ is expressed to apply notwithstanding any agreement to the contrary and that it is designed to protect authors, it might be possible to persuade a court that effect should be given to it.

\section{WHAT ABOUT INFRINGEMENT?}

In most disputes of this kind, what matters is ownership of the rights. Copyrights in musical works (including associated lyrics) are generally exploited through collecting societies (also known as collective management organizations). The issue is usually who can receive the distributions made by the collecting society in each jurisdiction, which depends on who owns the underlying local rights. If the analysis presented above is correct, then an author who enters into a worldwide assignment of his or her rights will be able to terminate the assignment of the U.S. copyright pursuant to $\S 203$ after thirty-five years even if the assignment is subject to English law and provides, when interpreted in accordance with English law, that the assignment may not be terminated. The author will then be able to receive the distributions from the relevant U.S. collecting society (ASCAP, BMI, SESAC, Global Music Rights, or Pro Music Rights). That will not assist the author so far as distributions from non-U.S. collecting societies are concerned, however.

In a world where copyrighted works, and particularly musical works, are increasingly exploited by streaming, there is a further aspect to the problem that requires consideration. What if the author successfully recovers the U.S. rights and then either the author or a licensee starts streaming the work from a U.S. server

REPORTER: THR ESQ. (Jan. 18, 2017), https://perma.cc/GW24-HY6E. The case was settled out of court, but it is understood that he intended to rely upon Corcovado v. Hollis. The decision in the Morricone case would have enabled him to argue that the notices were effective even if English law applied to the interpretation of the contracts of assignments.

61. It will be a rare case in which Article 3(3) of the Rome Convention or Article 3(3) of the Rome I Regulation is available, because that would require all other elements relevant to the situation to be located in the United States.

62. Corcovado does provide some support for the argument, however. 981 F.2d at 685 ("Factors arguing for the application of United States law include the following: United States renewal copyrights reflect a vital policy of United States copyright law ....”). 
without geoblocking foreign recipients? Clearly the author will not infringe the author's own U.S. copyright. Nor will the author's licensee. But will the author or licensee infringe the non-U.S. rights which are still owned by the assignee? We will consider this question from the perspective of European, or more specifically U.K., law. In other words, can the assignee allege that the author or licensee infringed a U.K. or EU member state copyright? Or can the author rely upon the fact the streams emanate from a territory in which the author owns the copyright? We shall assume for this purpose that the author or licensee is amenable to the jurisdiction of the courts in England.

The choice of law question in these circumstances is what law applies to the allegation of infringement. Article 8(1) of EC Regulation 864/2007 (the "Rome II Regulation") provides that "[t]he law applicable to a non-contractual obligation arising from an infringement of an intellectual property right shall be the law of the country for which protection is claimed," that is, the lex loci protectionis. ${ }^{63}$ It follows that an English court considering a claim by the assignee for infringement of the U.K. copyright ${ }^{64}$ would apply U.K. law to this question. U.K. copyright law has been substantially harmonized with that of the EU Member States by virtue of a series of EU Directives.

The relevant right for this purpose is the right of communication to the public by wire or wireless means, which includes making works available to the public in such a way that members of the public may access them from a place and at a time individually chosen by them, under Article 3(1) of EC Directive 2001/29 (the "Information Society Directive"). ${ }^{65}$ The Court of Justice of the European Union ("CJEU") has interpreted Article 7 of EC Directive 96/9 (the "Database Directive") 6 as meaning that the sending by one person, by means of a web server located in Member State A, of data from a database protected by database right to another person located in Member State B for storage and display on the latter's computer constitutes an act of "re-utilisation" of the data by the person sending it which takes place in at least Member State B, where there is evidence from which it may be concluded that the act discloses an intention on the part of the person performing the act to target members of the public in Member State B. ${ }^{67}$ Applying this reasoning to Article 3(1) of the Information Society Directive, Arnold J held, in EMI Records Ltd. v. British Sky Broadcasting Ltd., that the act of making available occurs both in the state where the communication originates and in the state where it is received if it is

63. Regulation 864/2007/EC of the European Parliament and of the Council of 11 July 2007 on the Law Applicable to Non-Contractual Obligations, art. 8(1), 2007 O.J. (L 199).

64. Following the decision of the U.K. Supreme Court in Lucasfilm Ltd. v. Ainsworth [2011] UKSC 39, [2012] 1 AC 208, the English court may also have jurisdiction to entertain claims for infringement of foreign copyrights, which would require the application of the relevant foreign copyright laws.

65. Directive 2001/29/EC of the European Parliament and of the Council of 22 May 2001 on the Harmonisation of Certain Aspects of Copyright and Related Rights in the Information Society, art. 3(1), 2001 O.J. (L 167).

66. Directive 96/9/EC of the European Parliament and of the Council of 11 March 1996 on the Legal Protection of Databases, art. 7, 1996 O.J. (L 77).

67. See Case C-173/11 Football Dataco Ltd v. Sportradar GmbH, EU:C:2012:642 (Oct. 18, 2012). 
targeted at the public in the latter. ${ }^{68}$ Assuming that this is correct, ${ }^{69}$ and that the stream in question is targeted at the United Kingdom, then the answer to the question posed above appears to be that the assignee will have a claim for infringement of U.K. copyright, and it will be no defense that the author owns the U.S. copyright.

The result would probably be the same if U.S. law were to be applied. In Spanski Enters. v. Telewizja Polska, S.A., the D.C. Circuit localized the act of public performance in the territory of receipt (although it may have left the door open to considering that a public performance also takes place in the country of emission). ${ }^{70}$ It held that, although it was in Poland that TV Polska digitally formatted and uploaded fifty-one television programs, infringing performances occurred on the computer screens in the United States on which they were shown. The Court gave good pragmatic reasons for considering that the act of public performance occurs in the country to which the stream is directed: "Given the ease of transnational internet transmissions, a statutory scheme that affords copyright holders no protection from [foreign webcasters who direct infringing performances into the United States] would leave the door open to widespread infringement, rendering copyright in works capable of online transmission largely nugatory.",71

\section{CONCLUSION}

As this discussion shows, the outcome of disputes concerning the U.S. right of termination can turn on the characterization of the controversy as one of contract or one of substantive copyright law. Characterization in turn leads to choice of law, pitting the undertakings secured by the national contract law chosen by the parties against limitations on the scope of grants imposed by the copyright laws of the countries for which rights are granted. Whether viewed from the perspective of U.S. law or that of English law, the key question is what law governs the permissible

68. EMI Records Ltd. v. British Sky Broad. Ltd. [2013] EWHC 379 (Ch) [38], [2013] FSR 31 [38] (Eng). It may be argued that, if anything, the place of reception is more important than the place of origin because on the Internet the point of origin is essentially arbitrary, and it can be hard to prove where it really is due to VPNs, proxies, mirror sites, and the like.

69. In Joined Cases C-24/16 and C-25/16 Nintendo Co. Ltd v. BigBen Interactive GmbH, EU:C:2017:724 (Mar. 1, 2017), the CJEU interpreted Article 8(2) of the Rome II Regulation, which provides that "[i]n the case of a non-contractual obligation arising from an infringement of a unitary Community intellectual property right, the law applicable shall, for any question that is not governed by the relevant Community instrument, be the law of the country in which the act of infringement was committed," as meaning that "the country in which the act of infringement was committed" refers to the country where the event giving rise to the damage occurred. Where the same defendant is accused of various acts of infringement in various Member States, the correct approach for identifying the event giving rise to the damage is not to refer to each alleged act of infringement, but to make an overall assessment of that defendant's conduct in order to determine the place where the initial act of infringement at the origin of that conduct was committed or threatened by it. It might be argued that this move towards applying a single law to cases of ubiquitous infringement should be extended to Article 8(1) of the Rome II Regulation, but it seems doubtful that the CJEU would accept such an argument given the statement in recital (26) of that Regulation that "the universally acknowledged principle of the lex loci protectionis should be preserved."

70. Spanski Enters. v. Telewizja Polska, S.A., 883 F.3d 904 (D.C. Cir. 2018).

71. Id. at 916 . 
scope of an author's grant. Given that copyright is territorial, as a matter of principle, one would expect that law to be the lex loci protectionis, and that is essentially what both U.S. law and English law stipulate. Where the copyright is a U.S. copyright, application of the lex loci protectionis in accordance with the conceptualization suggested by Morricone leads to the conclusion that $\S 203$ cannot be overridden by a contract subject to a different law.

It may be asked what, if any, limits there are to this principle. Does a multinational grant incorporate every national law limitation on the scope of the grant, including, for example, provisions as to language (such as requirements for new modes of exploitation expressly to be included) or formalities (such as requirements that the grant be signed by the author or even witnessed)? It is tentatively suggested that not every limitation will be incorporated, but only those which amount to a substantive restriction on the transferability of the copyright rather than an evidential or procedural requirement. As to which limitations amount to a "substantive" restriction, the private international law rule is that the law which determines the scope of the grant is the lex loci protectionis. Limits on the scope of the grant which are substantive, when characterized in accordance with that law, must be given effect, but not limits which are evidential or procedural.

In any event, the principle of territoriality is a two-way street: Termination of the grant of U.S. rights does not affect the ownership of rights granted for other territories. As a result, the author, or her new grantee, must confine her exploitation to the United States. For physical copies or for territorially restrained modes of communication to the public, such as broadcasting, confining exploitation to the United States seems feasible. The author may not, however, undertake modes of communication that will deliver the work beyond U.S. borders, to countries where her prior grant continues in force. By the same token, the original grantee remains free to continue exploiting the work outside the United States. Would this freedom in addition allow the original grantee to communicate the work from the United States to other countries (for example, by streaming), so long as in making the work available to users abroad, the exploiter does not also render it accessible within the United States? The answer to that question depends on the suggestion of the Spanski court (and, for that matter, by EMI Records v. British Sky Broadcasting) that the act of public performance (or of making available) may occur both in the place(s) where the communication is received and in the place from which it was sent. If one localizes the act of public performance or making available at the point of origin of the communication (as well as at the places of receipt), then the terminated grantee may not communicate the work from the United States even if he succeeds in geoblocking U.S. reception of the work. 